\title{
How to improve the teaching ability of university teachers based on MOOC
}

\author{
LUJIANFEI
}

Nanchang Teachers College,Nanchang, Jiangxi Province, China

kcaj@163.com

Keywords: MOOC、 teaching ability、 teacher development center、science and education integration. Abstract.: Massive Open Online Courses rise in the world Bring great competition and challenge for the traditional university teaching. Massive Open Online Courses have The richness of the resources, the flexibility of the teaching methods, the democracy of the teaching idea, which Prompted the university teachers to develop curriculum resources, strengthen teaching design, improve teaching methods, improve teaching skills, Establish the concept of Students-centered, promote the transformation of "teaching paradigm" to "learning paradigm". How to improve the teaching ability of university teachers based on MOOC, The key is to improve the technical level of teachers, to promote the development of teachers themselves, to promote the quality of education and teaching.

\section{The impact of MOOC on traditional university teaching}

MOOC learning resource rich, promote teachers to develop curriculum resources, designed to enhance teaching

MOOCS have a considerable wealth of high-quality teaching resources, launched a large number of famous teachers and online courses for students to choose and the new curriculum line speed very quickly. Students can be based on their own interests or development needs, to facilitate and quickly find the world's highest level of curriculum.

the flexibility of MOOC teaching means, promote teachers to improve teaching methods, improve teaching skills

MOOC to take Classroom Flippedteaching force in the implementation of high-quality video curriculum resources instead of "face to face teaching". "Flipped classroom" refers to the information environment, students in the classroom to watch and learn from teachers to do a good job of teaching video, classroom teaching and learning between teachers and students to study and solve problems in the workplace. "Flipped classroom" teaching video dapper, clear teaching information, learning process re construction, review the detection is fast and convenient. In addition, MOOC website for students to learn the process of the entire record, such as repeated watching the video clips, repeated mistakes exercises, the length of time to learn the knowledge point of contrast, etc.. Through the analysis of the data and further mining, it can be in-depth analysis of the knowledge of the students, the experience and knowledge of the skills, but also for the individual to provide more targeted guidance to lay the foundation. In the teaching design, MOOC uses an objective and automated online assessment system, such as the test, along with the examination, the same group review and other forces in one with the students to interact and respond. Visible, MOOC flipped classroom subversion of the traditional teacher education + student job, one way to teach the paradigm, both to help promote the improvement of teachers' network teaching skills, but also help to promote teachers.

MOOC teaching idea of democracy, promotes the teacher set up "take the student as the center" concept, to promote the teaching paradigm "to" learning paradigm shift

MOOC for the democratization of higher education had a positive and far-reaching impact, leveraging the deep-rooted traditional university classroom, through the University of barriers. MOOC provides a unique opportunity for people to learn how to learn and learn at any time and at any time in a large open network. MOOC philosophy core is "take the student as the center, highlighting is to" learn "the value orientation of teaching and students' learning autonomy, breaking the traditional" teacher as the center, to teaching as the center, the classroom as the center "teaching mode. Creative 
learning ability as the center for personalized teaching, guiding model transformation, the higher education from the industrial age to information age must be completed by the historic change.

\section{MOOC times to enhance the teaching ability of University Teachers}

\section{to teacher (Teaching) development center to rely on, provide guidance and services}

to improve the teachers' teaching ability, MOOC, with the rapid development of the trend of the times, the improvement of teaching ability of university teachers in addition to the need to reflect on their own teaching ability efforts and, also need to special information technology personnel for providing technical support and help, need to have a group of rich teaching experience and professional staff for providing counseling and teaching guidance. Teacher (Teaching) development center is a very good platform.

First, teacher (Teaching) development center to provide teaching resources support services, help teachers to widen the field of vision, understanding, learning, reference at home and abroad more advanced and effective teaching theory and practice method, and new student learning in duplicate, evaluation), so as to promote teachers' development has the brand effect of the seminar course, students personalized to meet the training requirements.

Secondly, teacher (Teaching) development center provide service of teaching skill training, teachers' teaching ability enhance build communication platform, provide advice and guidance to solve in the practice of teachers teaching concrete difficult problem, meet the personalized teacher professional development needs.

The establishment of teacher (Teaching) development center is an important measure to improve the teaching ability of high level university, and it is also an objective requirement to promote the process of teacher professional development. Teachers' professional development requires teachers to have a higher teaching ability and teaching level, the maturity of teaching skills has become an important part of teacher specialization.

In our country, the establishment of the University Teachers (Teaching) development center is the beginning of the last few years. With the further deepening of the teaching reform of undergraduate education, improving the teaching ability of teachers has become a key link to improve the level of personnel training. China's education authorities are fully aware of this, through the introduction of a number of policies to support the construction of the University Teachers (Teaching) development center. The State - and long term educational reform and development plan (2010-2020) "made it clear that to improve teachers' professional level and teaching ability of the college undergraduate teaching quality and teaching reform project" also made it clear that to to enhance the teaching ability of teachers, to guide the higher school to establish suitable for the characteristics of the University Teacher Education Development Center, and actively carry out teacher training, teaching reform, research, communication, quality assessment, advisory services and the work, improve the school young teachers' teaching ability, training characteristics to meet the teachers' personal and professional development and personnel need to call. Obviously, the teacher (Teaching) development center is an internal support system to improve the teaching ability of university teachers, and it is also a common practice to improve the teaching ability of university teachers at home and abroad. In the face of the impact of the MOOC, the major colleges and universities should be based on the teacher (Teaching) development center, improve the university teaching promotion mechanism, in order to enhance the teaching ability of teachers to provide support and services.

with the integration of science and education as a breakthrough, through research teaching to enhance the teaching ability

With the development of network technology, psychological science and educational science, MOOC "on the development of students as the center, with students as center, in order to study the effect as the center of the value concept is deeply rooted in the hearts of the people, interactive digital age learning leveraging the traditional classroom teaching mode, push from" accept type study "to" active learning "steering. Traditional university teaching begins to pay attention to the "student 
centered"". "Taking students as the center" is not the division of the role, identity and status of teachers and students, but the transformation of teaching concept, management concept, service concept, teaching method and evaluation method. At present, rely on China's university teaching is still rigid curriculum and teachers in the classroom teaching, deviated from the "student-centered", teachers of conservativeness, lack of the teaching method innovation research ability.

In a sense, our university teachers lack of teaching reflective consciousness and innovative ability and university research, light teaching utilitarian orientation not unrelated. In the context of the MOOC era, breaking the path dependence, the key is to focus on the "student centered", to the integration of science and education as a breakthrough, to carry out research based teaching.

Research oriented teaching requires the idea of the integration of science and education, and the integration of science and education is based on constructivism. Constructivism to promote to students as the center, play the main role of the individual cognitive, asked the students in real situation to take the initiative to collect and analyze relevant information, on issues related to the proposed various assumptions and to verify, through exploration and discovery to construct the meaning of knowledge. Teachers as students learning partners should be given to the students to solve the problem of autonomy. It can be said that constructivism has fundamentally shaken the teaching paradigm, which lays a solid foundation for the new teaching logic of "learning paradigm". The integration of science and education is a new teaching model developed under the guidance of this theory.

The integration of science and education aims to break the "teaching mode" of traditional teaching, and set up the "learning paradigm" of "taking students as the center", and exert the educational function of scientific research. Integration of science and education is the scientific research and teaching closely together, to first-class scientific research training first-class talents: Yili side, the curriculum is the carrier of the integration of science and education, teachers should the course content and transformation of lesson plans and handouts, for students to provide the most cutting-edge knowledge, focus on the cultivation of students' creative thinking, critical thinking, scientific spirit and scientific research ability for scientific research achievements transformation. Fusion of science and requires teachers to study teaching itself, through teaching and research to stimulate scientific research, leading the research and teaching with scientific research, to provide empirical support for the teaching of academic; through the attention and following the science and technology and the development of the discipline frontier, according to the actual demand of the social development and the students, improve the ability of teachers to develop new curriculum resources and improve teaching academic content. In fact, the integration of teaching and learning in the teaching force is also a test of the academic ability of teachers. Scientific research ability is the foundation and premise of teaching ability, teaching ability is the continuation and deepening of scientific research ability, they are two pillars of teaching academic ability.

Integration of science and education will help to realize from the "Teacher centered" teaching mode to "take the student as the center" teaching mode is to achieve effective means of teaching, research and promote each other, teachers can guide and promote the university teachers consciously strengthen the teaching of reflection and study. For example, what kind of scientific research is the students interested in what kind of scientific research results can be used as the teaching content, how to transform the research results into teaching materials, how to carry out the integration of science and education

In short, in the context of the MOOC era, in the increasingly fierce competition in the field of higher education, improve the teaching ability of teachers, to maintain the traditional classroom competitiveness has become the basic strategy of every university. Construction of teachers (Teaching) development center, adhering to the teaching concept of science and education integration, to support the high level of scientific research teaching should be the path to improve the teaching ability of teachers. This is not only to deal with the objective requirements of the MOOC challenge, but also the inherent need of teachers' self-development. 


\section{References}

[1]BaiduEncyclopedia.Coursera[EB/OL].http://baike. baidu. com/vicw/9937855. htm.2013-12-11.

[2]Andies van Dam, Andrew S.forsberg et.al. Immersive VR for Scientific Visualization :A Progress Peport[R].IEEE Computer Graphics and Applications.2000.11 .27.

[3] MOLNAR S,EYLES J, POULTON J. PixelFlow: high-speed rendering using image composition; proceedings of the ACM SIGGRAPH Computer Graphics, F, 1992 [C].ACM.

[4]Constance Cook. To improve the teaching ability of university teaching center, the role of [M] Chen Jin, Zheng Yaoli, translated. Hangzhou: Zhejiang University press, 2011

[5]Liu Xianjun. Theory of "taking students as the center" [J] higher education research, 2012, (8)

[6] Maekness,J. ,S. F. J. Mak, R. Williams. The Tdeals and Reality of Participating in a mooc[C]Proceedings of the 7th international Conference on Networked Lcarning,2010. 